\title{
ANALYSIS PRAGMATIC STUDY ON DEIXIS IN THE ARTICLES JAKARTA SPORT
}

\author{
Resti Nur Setiakawanti ${ }^{1}$, Elsa Susanti ${ }^{2}$ \\ ${ }^{1}$ IKIP Siliwangi \\ ${ }^{2}$ IKIP Siliwangi \\ 1'park.resti@gmail.com, ${ }^{2}$ elsasusanti17@gmail.com
}

\begin{abstract}
The purpose of this research is to identify deixis forms and meanings used in Jakarta post articles. This study was applied qualitative descriptive. Then, it was analyzed by using the Dylgjeri and Kazazi concept the data was table from in article Jakarta Post. The findings indicate that the types of deixis found in articles selected from the Jakarta Post are the first person there are I, Me, My, We, and Our (In third person there are She, Her, His, Him, and They), deixis spatial (there are school, class, hospital, on the stairs, world, here and there.), and temporal deixis. (there are now, then, five month ago, today, and yesterday). The results of this study show that person deixis is used 157 times and have percentage $66.5 \%$ spatial deixis is used 54times and have percentage $22.8 \%$ and temporal deixis is used 25times and have percentage $10,5 \%$
\end{abstract}

Keywords: Pragmatic, Deixis

\section{INTRODUCTION}

Pragmatics is the study of aspects of meaning that depends on the context that is systematically abstracted away from within the construction of content or logical form (Pupier, 2006). (Yule \& Stalnaker, 1996) said that "pragmatics is concerned with the study of meaning as communicated by a speaker (or writer) and interpreted by a listener (or reader)." Therefore pragmatic is a branch of linguistics that learns about the meaning of words conveyed by speakers.

In pragmatic we can learn deixis. Deixis is one part of the study in pragmatics that studies about appointment something by language. Deixis is important to learn of language especially for us learns English as second language because usually some people have difficulties to understand the intention of the speaker, by study deixis it will make easier to communicate using context. Deixis is important part to learn language especially more important to us when learn second language.

According to Lyons (1981:170) in (Eragbe, Yakubu, \& State, 2015) "Deixis is like reference by means of an expression whose interpretation is relative to the usually extra linguistic context of the utterances, such as who is speaking, the time and place of speaking, the gesture of the speaker, or the current location in the discourse." 
Moreover, (Yule \& Stalnaker, 1996)states that deixis is derived from Greek, which is a technical term to point something using language. George Yule classify deixis by indicating person through person deixis (me, you), location through spatial deixis (here, there), or time through temporal deixis (now, then).

\section{Deixis}

According to (Yule \& Stalnaker, 1996) deixis is pointing at something through language. Deixis is an important field studied in pragmatics, semantics and linguistics. Supported by (Cairns, 1991) deixis is very important in dialogue because it serves to hold participants to a certain point in space and time. Without an anchor like that each dialog will appear as a loose collection that is disconnected Speech - which is definitely not. This dialogue is very significant in the context of which some of the deictic references relate to that context.

Deixis on phenomena where the meaning of certain words and phrases in a speech requires contextual information. The word or phrase that requires contextual information for taxation is deictic, and furthermore. Deixis the product of the ways in which the language encodes, features of the context of utterance and thus also concerns ways in which the interpretation of utterance/es depends on the analysis of thatcontext of utterance (Dylgjeri \& Kazazi, 2013).

Based on Lyons (2003:170) in (Eragbe et al., 2015) "Lyon further points out that deixis are a grammaticaldevice in many languages categorized as person andtense. The person deixis refer to the participants in adiscourse-the speaker, the hearer and sometimesthe referent in the real world. On the other hand,tense echoes the time of interaction or occurrenceof events. The linguistic features used to locate timeplace or persons in communication encounter iscalled deixis. Generally,deixis performpointing ororientation functions in discourse." thus:"

(Dylgjeri \& Kazazi, 2013) stated "identify three types of deixis and explained them

1. Person deixis: personal deixi is used to point to objects as this, that these, and those (demonstratives) and people(her, him, them, me(pronouns)

2. Spatial deixis, which is used to point to a location (here,or there,)

3. Temporal deixis, which is used to point to a time (now, then, next week, last month) She is also of the view that in order to interpret all these deictic expressions, we must know which person, time and place the speaker has in mind. There is a great difference on what is close to the speaker (this, here, now) and what is distant (that, there, then). We can also realize whether there is a movement away from the speaker (go) or there is a movement towards the speaker (come)

\section{Types of deixis}

\section{1) Person deixis}

Based on (Li, 2009) the deixis are an important component of pragmatics. With the recipient at the address, the recipient and the third party involved in the conversation, the person deixis denotes social status, interpersonal relationships and other factors of the conversation.

(Eragbe et al., 2015) states that "Person deixis are the personal pronouns such as thefirst, second and third used as a means of locatingthe referents in relations to the events taking placein the discourse. The texts subjected to analysisexhibited the use of person deixis for locating theinsurgents and their victims in discourse. Theexcerpt below shows 
some examples." "Weare extremely concerned about thehumanitarian situation, as several thousandpeople are at present without any assistance."

\section{2) Spatial deixis}

Spatial Dixies is used to select a location relative to the speaker or recipient's location (Vaysi \& Salehnejad, 2016). According to Saeed in (Vaysi \& Salehnejad, 2016) stated, "systems of spatial deixis are also used in other domains. Forexample they are often used as a form of orientation within a discourse, in what we couldtherefore call 'discourse' or 'textual deixis', as when we say:"

- Here our argument runs into some difficulties.

- At this point we have to look back to our initial premises. In many languages too, spatial deixis terms, such as demonstratives, are extended to refer totime. An example of this use of the demonstratives is below:

- That year was much hotter than this one is.

Based on (Eragbe et al., 2015) "in considering spatial deixis, however, it is important to remember that location from the speaker perspective can be fixed mentally as well as physically. Based on (Yule \& Stalnaker, 1996) "categorized spatial deictic into two forms deictic projection and psychological distance."

\section{a. Deictic projection}

Deictic projectionis accomplished via dramatic performance when I used speech to represent the person, location, and feelings of someone or something else. For example:

'I will be right here waiting for you'

Proximal term of Here means the location of the speaker.

\section{b. Psychological distance}

Psychological distanceis the truly pragmatic basis of deixis. Physically close objects will tend to be treated by the speaker as psychological close. Also something that is psychological with generally.

For example:

'The man over there 'Distal term of over there is refer to the location of the man is far from the speaker. The speaker who utters it and the word the man could be referred to someone, which consider as a man and know by the speaker and the speaker and the hearer.

In addition, "spatial deixis refers to the physical and social environment or simply the space around theparticipants in a discourse. The most commonly usedwords as spatial deixis are the demonstrativepronouns this, that, these and those. Other wordsoften used as deixis include here, there, in, on, at etc (Eragbe et al., 2015)."

\section{3) Temporal deixis}

Time or temporal deixis is a reference for time relative to a temporal reference point, this point is the moment of utterance in which when speaking or written (Dylgjeri \& Kazazi, 2013). Temporal dixies shows the orientation or position of actions and events in time. English and The Persians have lexical words and phrases naturally characterized for temporal dixies, such as English terms now, then, yesterday, today, tomorrow, last year, next year, etc. and their Persian counterparts like 'hala', 'sepæs','diru: z ','færda','parsal','sal- e-? ajænde', etc. In addition, temporal dixies can be 
marked through tension, which is encoded in form verbs with affixes or expressed in independent morphemes (Vaysi \& Salehnejad, 2016).

Moreover Yule 1996:14 stated that "the forms of temporal reference are learned a lot later than the deictic expressions like yesterday, tomorrow, today, tonight, next week, last week, this week. All these expressions depend for their interpretation on knowing the relevant utterance time."

\section{METHOD}

Method of data collection that is used by researcher is documentary technique. Documentary technique means that the data are found from reading, studying, and analyzing by identification and classification to collect required information related to the study.

The writer does the following procedures:

(1) Collecting the data,

(2) Reading and observing the data,

(3) Finding the data, putting sign and making checklist on it,

(4) Taking the data and presenting them in data display, and

(5) Drawing and finding conclusions.

The researcher obtains the data from the editorial of Jakarta post; the data are analyzed in following steps. First, the researcher describes the types of deixis (person deixis, spatial deixis and temporal deixis) based on the Dylgjeri and Kazazi theory. Finally, the researcher make conclusion on the result of analysis.

\section{RESULTS AND DISCUSSION}

\section{Results}

In newspaper articles Jakarta Post the researchers found three types of deixis, there are person deixis (as first person, as second person and as third person), spatial deixis and temporal deixis (present, past and future). The researcher was count the frequency of this deixis, and the result are:

Table 1. The number and percentage of the types of deixis in each article

\begin{tabular}{|c|c|c|c|c|}
\hline \multirow{2}{*}{ Heading of Newspaper } & \multicolumn{3}{|c|}{ Types of Deixis } & \multirow{2}{*}{ Number } \\
\hline & Person & Spatial & Temporal & \\
\hline $\begin{array}{l}\text { Football Star Ronaldo Spurs Portugal Hotel } \\
\text { Chain's Attack Overseas }\end{array}$ & 42 & 43 & 2 & 87 \\
\hline $\begin{array}{l}\text { FIFA Unveils Yashin-Themed Poster for } \\
\text { Russia's } 2018 \text { World Cup }\end{array}$ & 7 & 8 & 2 & 17 \\
\hline $\begin{array}{l}\text { Barca Draws at Title Rival Valencia After } \\
\text { Goal-Line Controversy }\end{array}$ & 30 & 2 & 9 & 41 \\
\hline $\begin{array}{l}\text { Denmark Rout Ireland With Eriksen Treble to } \\
\text { Reach World Cup }\end{array}$ & 36 & 1 & 7 & 44 \\
\hline $\begin{array}{l}\text { City Opens Up 11-Point Lead Over United } \\
\text { With Derby Win }\end{array}$ & 43 & - & 5 & 48 \\
\hline The number & 158 & 54 & 25 & 237 \\
\hline The percentage & $66,6 \%$ & $22,7 \%$ & $10,5 \%$ & $100 \%$ \\
\hline
\end{tabular}

Table 1 shows the number and the percentage of the usage of deixis in the newspapers article, person deixis is used 157 times and have percentage 66,5\% spatial deixis is used 54 
times and have percentage $22,7 \%$ and temporal deixis is used 25 times and have percentage $10,5 \%$.

\section{Discussion}

The researchers by this research were chosen deixis to analyze scripts newspaper articles Jakarta Post. In this research the researchers were examine three types of deixis, namely: person deixis, temporal deixis and spatial deixis. Then the researchers found many deixis in the three types of deixis.

According to the research the researchers found:

1. Person deixis in first person there are I, me, my, we, and our. In second person there are you and your. In third person there are she, her, his, him and they.

2. Spatial deixis there are school, class, hospital, on the stairs, world, here and there.

3. Temporal deixix there are now, then, five month ago, today and yesterday.

The researchers were to count the percentage of this deixis:

1. Person deixis is used 158times and has percentage $66,6 \%$

- First person is used 13times and has percentage $5,4 \%$

- Second person is used 111times and has percentage 46,8\%

- Third person is used 34 times and has percentage 14,3\%

2. Spatial deixis is used 54 times and has percentage $22,7 \%$

3. Temporal deixis is used 25 times and has percentage $10,5 \%$

\section{CONCLUSION}

In this paper we have shown the types of analytic newspaper articles Jakarta Post, it can be concluded that there are three types of deixiswhich are used in article of Jakarta Post namely person deixis, spatial deixis and temporal deixis. The most dominantly types of deictic word which is used in article Jakarta Post is 158 occurrences person deixis $(66,6 \%)$. The dominant deictic word pointing to the second person deixis is 111 times and has percentage $46,8 \%$.

\section{ACKNOWLEDGMENTS}

Researchers enormously grateful to Allah SWT and our parents for her continuous encouragement, kindly advice throughout our study and researchers thankful our lecturer for kind advice and help.

\section{REFERENCES}

Cairns, B. (1991). Spatial Deixis. English, 38.

Dylgjeri, A., \& Kazazi, L. (2013). Deixis in Modern Linguistics and Outside. Academic Journal of Interdisciplinary Studies, 2(4), 87-96. https://doi.org/10.5901/ajis.2012.v2n4p87

Eragbe, C., Yakubu, S., \& State, T. (2015). Research Article the Use of Deixis and Deictic Expressions in Boko Haram Insurgency Reports : a Study of Selected Boko Haram Insurgency Reports By the Media Federal Universty, Wukari, Nigeria Faculty of Humanities, Management and Social Sciences Depart, 3(Yule 2006).

Li, Y. (2009). A Social and Pragmatic Analysis of the Second Person Deixis You. Asian Social Science, 5(12), 130-133.s 
Pupier, P. (2006). The Handbook of Pragmatics (review). The Canadian Journal of Linguistics / La Revue Canadienne de Linguistique, 51(1), 85-94. https://doi.org/10.1353/cj1.2007.0028

Vaysi, E., \& Salehnejad, L. (2016). deixis in Eng and Persian, 3(1), 1405-1414.

Yule, G., \& Stalnaker, R. (1996). Pragmatics. Synthese. Retrieved from http://philpapers.org/rec/STAP-7\%5Cnhttp://www.amazon.com/Pragmatics-OxfordIntroductions-Language-Study/dp/0194372073 